\title{
Elusive Justice for Victims of the Abdoulay Yerodia International Crimes of August 1998 in the Democratic Republic of the Congo
}

\author{
Jean Pierre Mujyambere*
}

https://doi.org/10.21827/GroJIL.7.2.164-181

\author{
Keywords \\ VICTIMS; INTERNATIONAL CRIMES; YERODIA; DEMOCRATIC REPUBLIC \\ OF CONGO; TUTSI; INTERNATIONAL COURT OF JUSTICE
}

\begin{abstract}
In order to access justice, victims of human rights abuses must first find a jurisdiction that is willing to hear their case. In the Abdoulay Yerodia Ndombasi (Yerodia) case in the Democratic Republic of Congo (DRC), victims of Yerodia's intentional crimes brought their case in Belgium because they were unable to introduce it in domestic courts. Belgium launched an international arrest warrant against Yerodia who, at the time of accusation by Belgium, was Foreign Minister of the DRC. This has led to a dispute between the DRC and Belgium before the International Court of Justice (ICJ). The DRC accused Belgium of violating the diplomatic immunity of its Foreign Minister. However, the international crimes in question were committed before Yerodia became Foreign Minister of the DRC and the ICJ rendered its decision in his case after he had ceased to hold that position. Despite this, the ICJ ruled in favor of Yerodia's diplomatic immunity and consequently this decision has only protected him from criminal liability. This paper examines first the historical background of the discrimination of Yerodia's victims to support the claim that they cannot access justice in the DRC. It also argues that the ICJ's decision in this case has only contributed to shielding Yerodia from justice rather than preserving smooth operation of the DRC's diplomatic activities abroad. Finally, this paper suggests that the ICJ's decision in this case has closed the doors to victims in their endeavors to access justice.
\end{abstract}

\section{Introduction}

It has been more than two decades since the DRC witnessed conflicts in which a plethora of gross violations of human rights occurred in the context of targeted inter-ethnic violence. Most crimes committed during this violence remain unpunished, a situation that may contribute to their reoccurrence in the future. These tragic events include the massacres of the Tutsi in August 1998. The immediate trigger of these killings were certain speeches advocating racial hatred, which were made during the outbreak of the second civil war in August 1998 by some high ranking authorities in the DRC including, among others, the late President Laurent Désiré Kabila and his former Private Secretary and Chief of Cabinet

LLM in International and Public European Law at Erasmus University of Rotterdam; Advanced Master's in Human Rights from the Leuven Academy in Belgium; Researcher at the Human Rights Center in the Department of European and Public International Law of the Faculty of Law and Criminology of the University of Gent, Belgium. 
Yerodia. ${ }^{1}$ That war was fought in opposition to the Kabila regime by the rebels of the Rally for Congolese Democracy (RDC) and the Movement for the Liberation of Congo (MLC). Officially, the rebels claimed to oppose the expansion of a new dictatorship in the DRC. ${ }^{2}$

To respond to the insurgency, the Kabila regime mobilised members of other Congolese communities to exterminate the Tutsi in the DRC. The Tutsi were accused of conniving with foreign forces to destabilise the country and were referred to as 'scum and vermin that must be methodically eradicated and with determination. ${ }^{3}$ Although at time of writing no research has yet been conducted to identify the exact number of victims, these hateful speeches spread a destructive ideology against the Tutsi in the DRC which resulted in the massacres of thousands. According to Vollhardt, one of the characteristics of these speeches is dehumanisation of the victims. ${ }^{4}$ For example, during the 1994 genocide in Rwanda, the Tutsi were compared to 'cockroaches.' Similarly, in the DRC in August 1998, the Tutsi were compared to 'vermin and scum.'

Due to extensive involvement of the DRC's high-ranking officials in the heinous killing campaigns, victims were unable to bring their cases in domestic courts in the DRC. However, some family members of victims, who resided in Belgium, filed their actions in a Belgian court. ${ }^{5}$ On11 April 2000, Judge Damian Vandermeesch of the Brussels Tribunal of First Instance issued an international arrest warrant against Yerodia, in which he described the crimes committed as crimes against humanity and war crimes. ${ }^{6}$ The Yerodia arrest warrant was issued in a case which also investigated Kabila, his former Minister of information Didier, Mumengi, former communications manager in the presidential office, Dominque Sakombi, and his former Interior Minister, Gaeta Kakudji. ${ }^{7}$ In Belgium, this case was filed under the Belgian Law of June $16^{\text {th }} 1993$ as amended by the law of 10 February 1999. This law concerns the punishment of the grave breaches of international humanitarian law and provides Belgian courts with jurisdiction over international crimes such as genocide, crimes against humanity and war crimes, irrespective of the nationalities and residences of the victims and accused and the places where the alleged crimes took place. $^{8}$

Instead of cooperating with the Belgian justice system in order to hold a perpetrator of international crimes accountable for his wrongdoing, the DRC's authorities chose to shield Yerodia from justice. In this regard, they instituted proceedings against Belgium at the ICJ to seek cancelation of that arrest warrant. In its application, the DRC claimed a

1 Alberto Luis Zuppi, 'Immunity v. Universal Jurisdiction: The Yerodia Ndombasi Decision of the International Court of Justice' (2003) 63 Lousiana Law Review 309, 311-312.

2 Erna Sif Bjarnadóttir, 'Conflict In The Democratic Republic Of Congo: A Study Of "New Wars"' (Master thesis, University of Iceland 2017) 31.

3 Safari Chizungu, 'Yerodia Guerre Aux Tutsi RDC 1998' (10 October 2013) $<$ youtube.com/watch?v=gyajJhWgcQY> accessed 1 December 2019.

4 Johanna Ray Vollhardt, 'Destructing Hate Speech in DRC: A Psychological Media Sensitization Campaign' (2007) 5 Journal of Hate Studies 15, 26-27.

5 Zuppi (n 1) 311.

6 Case Concerning the Arrest Warrant of 11 April 2000 (Democratic Republic of the Congo v Belgium) (Judgment) (2002) ICJ Rep 3.

7 Cours d'Appel de Bruxelles, 'Arret $16 \quad$ Avril $2002 \quad$ (Yerodia)' $<$ competenceuniverselle.files.wordpress.com/2011/07/arret-16-avril-2002.pdf> accessed 1 December 2019.

8 Jan Wouters and Leen de Smet, 'The ICJ's Judgment in the Case Concerning the Arrest Warrant of 11 April 2000: Some Critical Observations' (2001) 4 Yearbook of International Humanitarian Law 373. 
violation of the functional immunity of its incumbent Foreign Minister by Belgium. ${ }^{9}$ The ICJ rendered its final judgment in this case a year and a half after Yerodia ceased to hold that position and ordered Belgium to cancel its arrest warrant. In its decision, the ICJ upheld the DRC's complaint. ${ }^{10}$

However, although the DRC's authorities used the outbreak of war in August 1998 to justify the massacres of the Tutsi nationwide, it is widely known that the Tutsi have been the subject of many forms of injustice on the basis of their ethnicity in the DRC for many years. Therefore, the first section of this paper examines the historical background of the discrimination and marginalisation of the Tutsi in the DRC, matters considered to be the direct precursor to the massacres of August 1998. Although the ICJ did not directly address the crimes of which Yerodia was accused in Belgium, its decision has contributed to shielding him from justice. The same decision obstructed the access to justice of the victims in the DRC as well as in other foreign judicial forums. Hence, the second section of this paper examines whose justice in this case (victims or perpetrator of international crimes) as well as the implication of the ICJ decision on victims' right to access justice.

\section{Historical Background of the Discrimination Against the Tutsi in the DRC: The Precursors to the Massacre in August 1998}

From the colonial period until the present, the Tutsi have undergone numerous injustices in the DRC because of their ethnicity. Since it has been proven in numerous cases that ethnic politics culminate in suspicions among communities and generate violence, ${ }^{11}$ this situation has resulted in the violation of many of their rights, including their right to life. Before the independence of 1960 , the colonial administration had put in place some policies that excluded the Tutsi from the governance of the DRC. For a better understanding of why the DRC's authorities called for the extermination of the Tutsi in August 1998, one needs to revisit the history of their discrimination and marginalisation in the DRC, as briefly discussed below.

\subsection{Exclusion of the Tutsi from Governance During Colonial Administration} 2.1.1 The Historical Settling of the Tutsi in the DRC

Although there is some controversy regarding the settling of the Tutsi in the DRC, many available historical sources confirm that they arrived in three main groups from the region which is today known as the countries of Rwanda and Burundi. The first group, known as 'Banyamulenge', was already present in the South Kivu province in Eastern DRC before the demarcation of the borders of African countries during the Berlin Conference that took place between 1884-1885. ${ }^{12}$ Some of the Banyamulenge were looking for pastures for their livestock; others fled the conflicts that occurred during the reign of Ruganzu II Ndoli of 1510-1543 and others fled the famine that occurred under the reign of Yuhi IV Gahindiro around 1746-1802, both from the former kingdom of Rwanda. ${ }^{13}$ The second group of Tutsi came to the DRC during Belgian colonial rule in the 1930s, under the migration waves known as 'the Transplantation of Rwandan and Burundian populations in the Kivu

9 Case Concerning the Arrest Warrant of 11 April 2000 (Democratic Republic of the Congo v Belgium) (Application Instituting Proceedings) (2002) ICJ Rep 3 [174].

10 Case Concerning the Arrest Warrant of 11 April 2000 (Democratic Republic of the Congo v Belgium) (n 6).

11 Emily Paddon and Guillaume Lacaille, Forced Migration Policy Briefing: Stabilising the Congo (Refugee Studies Centre, University of Oxford 2011) 6.

12 SL Rukundwa, 'The Banyamulenge of the Democratic Republic of Congo: A Cultural Community in the Making' (2009) 60 Theological Studies 369, 369-371.

13 ibid. 
provinces and recruitment of manpower to work in plantations and mines. ${ }^{14}$ Most of the members of this second group settled in the current North Kivu province. The third group came to the DRC fleeing persecution in Rwanda and Burundi, following ethnic conflicts which took place at various intervals between 1959-1961 and 1963-1973 after these countries became independent. ${ }^{15}$ However, members of this third group who came from Burundi returned to Burundi shortly after independence, and those who came from Rwanda returned to Rwanda after the 1994 genocide of the Tutsi. In other words, the Tutsi discussed in this article, who were victims of the massacres of August 1998 in the DRC, are the Banyamulenge and those who emigrated to the DRC in the 1930s.

The term 'Tutsi' is used in this article to include all members of the Tutsi community of the DRC, while the term 'Banyamulenge' refers specifically to the Tutsi who live in the high plateaus of the Uvira, Fizi and Mwenga zones in the South Kivu province, who settled in that region before the demarcation of the borders of the African countries.

\subsubsection{Colonial Administrative Policy Excluding the Tutsi from Governance}

The exclusion of the Tutsi from governance in the DRC began during the Belgian colonial administration. This colonial power regulated the administrative institutions for the first time in the DRC with the decree of 6 October 1891 . That decree simply recognised different local entities which already existed, but it simultaneously suppressed those which belonged to the Banyamulenge in the South Kivu province. ${ }^{16}$ Some experts on the region, such as Koen, argue that the creation of these native authorities by the Belgian colonial administration was only a strategy to control the local populations and to integrate their local authorities. ${ }^{17}$ Turner also confirmed the idea of controlling ethnic groups, but he added that during that period, the Banyamulenge were reputed to be uncooperative with the colonial administrative power and therefore were excluded from local administration. ${ }^{18}$ The geographer, Weis, also wrote towards the end of the colonial period that, during colonial rule, the Banyamulenge faced severe discrimination because they resisted paying taxes and participating in the population census, as well as because they threatened to rule over other Congolese communities and to reduce the influence of Europeans over the DRC. ${ }^{19}$ Other experts of the region attribute the suppression of the Banyamulenge chieftaincies in the South Kivu province by the colonial rule to the fact that they opposed its policy of land exploitation introduced in the 1930s. That policy focused on agriculture. The Banyamulenge opposed it as they were concerned for the survival of their livestock and, consequently, their local administrative entities were suppressed and annexed to those of other communities. ${ }^{20}$ In the North Kivu province, the situation was the same because the Tutsi and other Kinyarwanda-speaking communities, notably Hutu populations, were also denied access to customary powers because of their origin. ${ }^{21}$

14 FM Ndahinda, 'Collective Victimization and Subjectivity in the Democratic Republic of Congo: Why do Lasting Peace and Justice Remain Elusive?' (2016) 23 International Journal on Minority and Group Rights 137, 156.

15 ibid.

16 Rukundwa (n 12) 381-382.

17 Koen Vlassenroot, 'Citizenship, Identity Formation \& Conflict in South Kivu: The Case of the Banyamulenge' (2002) 29 Review of African Political Economy 499, 502.

18 Thomas Turner, The Congo Wars: Conflict, Myth \& Reality (Zed Books Ltd 2007) 81-82.

19 ibid.

20 Rukundwa (n 12) 381-382.

21 Jason Stearns and others, Banyamulenge: Insurgency and Exclusion in the Mountains of South Kivu (Rift Valley Institute 2013) 17. 
The denial of customary power to the Banyamulenge and other Tutsi, as well as other Kinyarwanda speaking communities during the colonial rule, has led to their exclusion from governance in the DRC and this issue has always been a subject of tension and conflict between the Tutsi and other communities in the DRC. This is because, in the DRC, indigenous authorities are regarded as highly important by the local population. Powers at the local level are defined mono-ethnically even though the inhabitants of a local entity come from different ethnic groups. ${ }^{22}$ For example, there is a collectivity of Bafuliru (one of the communities of the Uvira district in South Kivu), but the inhabitants of that entity are from different ethnic groups and this is the case in most local entities in the DRC. This exclusion has had a negative effect on the exercise of democratic rights by the Tutsi in the DRC because at time of writing many of their compatriots still consider them as foreigners in their own country, a sentiment which nourished their killings in August 1998.

\subsubsection{Ethnic Violence Against the Banyamulenge During the 1964 Post-colonial Conflicts}

The DRC gained independence on 30 June 1960, but six months later, on 17 January 1961, its first prime minister, Patrice Lumumba, was assassinated. ${ }^{23}$ Although Lumumba was not killed in a civil war, his death was the beginning of various types of conflict in the DRC. ${ }^{24}$ His former education minister, Pierre Mulele, launched an uprising against the Kinshasa regime, which he considered to have colluded with foreign powers to assassinate Lumumba. That insurrection reached the areas of Fizi, Uvira, and Mwenga in the South Kivu province where the Banyamulenge lived under the command of rebel leader Simba. ${ }^{25}$ Among Simba's commanders in that area was the late President Kabila, who had his headquarters in the Hewa Bora mountains in the Fizi District. Although members of other communities in South Kivu joined that rebellion en masse, the Banyamulenge were reluctant. Consequently, that conflict quickly turned into an inter-ethnic military campaign against the Banyamulenge, where they were brutally killed and their properties looted ${ }^{26}$ In other words, in the native region of the Banyamulenge in South Kivu, the postindependence conflict was turned into an inter-ethnic conflict between the Banyamulenge and the rebels led by the late President Kabila. In response, the Banyamulenge created a militia group called 'abagiriye' which means 'the warriors' in English or 'les guerriers' in French. These warriors played a major role in chasing President Kabila out from the mountains of Hewa Bora to Tanzania in $1967 .{ }^{27}$ President Kabila returned to the DRC political scene in 1996, where he was accompanied mostly by the same Banyamulenge and other Tutsi whom he fought against during the post-independence conflict of the 1960s.

It is remarkable that the call for the extermination of the Tutsi by the late President Kabila's regime in August 1998 had an element of this bitter historical past. In their messages, the DRC's authorities justified these killings 'as a means to resolve the problems

22 Mahmood Mamdani, Understanding the Crisis in Kivu: Report of the CODSRIA Mission to the Democratic of Congo (Center for African Studies 1997) 12.

23 Marianne Thamm, 'From Our Archives: The Assassination of Patrice Lumumba, the Ghosts of History and the Policing of Remembrance' (Daily Maverick, 2016) <dailymaverick.co.za/article/2016-01-22-theassassination-of-patrice-lumumba-the-ghosts-of-history-and-the-policing-of-remembrance/> accessed 1 December 2019.

24 Jonathan Cole, 'The Congo Question: Conflicting Visions of Independence' (2006) 43 Emporia State Research Studies 26, 27.

25 Stearns and others (n 21) 16.

26 ibid.

27 Jason Stearns and others, Mai Mia Yakutumba: Resistance and Racketeering in Fizi, South Kivu (Rift Valley Institute 2013) 16. 
of the Tutsi in the DRC once and for all.' As a significant number of the soldiers and politicians from the Tutsi community in the east of the DRC had rallied the rebellion, the late President Kabila's regime likely had the goal of revenge, because the Tutsi (Banyamulenge) had contributed to the blocking of his political ambitions since the 1960s, after independence. This can be deduced from many of his speeches that followed the outbreak of war in 1998. In his various public speeches, the late President Kabila indicated that the liberation war in the Congo begun during the 1960s insurrections against neocolonialism rather than with the Alliance des Forces Démocratique pour la Libération du Congo (AFDL) in October 1996. ${ }^{28}$ In other words, the killing of the Tutsis of August 1998 in the DRC was not a spontaneous reaction by the DRC's authorities to the outbreak of the war in the two Kivu provinces. Rather, it had a correlation with the past relationship of the Tutsi with those in power, especially the late President Kabila and Yerodia, who were among the rebellion leaders during the post-colonial conflicts.

\subsubsection{Controversy over the Congolese Nationality of the Tutsi}

The question of the ethnicity of the Tutsi in the DRC was also manipulated by politicians during the Mobutu regime. In the 1970s, when Mobutu realised that he had totally defeated the post-independence insurrections in all parts of the country, he began to consolidate his power by exploiting ethnicity. A debate on the Congolese nationality of the Tutsi and other Kinyarwanda-speaking peoples in the DRC was discussed at the national level from the 1970s. ${ }^{29}$ This debate brought the Zaire/DRC parliament to adopt a law in 1972 that granted nationality to all persons who arrived in the DRC before 1959. This law replaced that of 1964, which considered as Congolese only those persons who were in Congolese territory before October $1908 .{ }^{30}$ However, the law of 1972 was heavily criticised by many politicians in Zaire/the DRC, as a result of the growing influence of the Tutsi in the Mobutu regime. ${ }^{31}$ In 1981, the law of 1972 was amended and the cut-off date was moved back to that in the law of 1964 because it limited Zairian/DRC citizenship to the descendants of tribes which were established in the Congo/DRC before August $1885 .{ }^{32}$ Technically, that law did not affect the Banyamulenge because they were already established in the Kivu region before that period. However, this legislation was applied to all the Tutsi without exception. Consequently, they were denied the right to vote and to stand as candidates in the parliamentary elections that took place between 1982 and 1987 due to 'dubious nationality.' ${ }^{33}$ Moreover, in April 1987, the Zaire/DRC government ordered a census of the Banyamulenge in the Vyura locality (in the districts of Moba and Kalemie of the current Tanganika province) in order to exile them to Rwanda. However, the Banyamulenge boycotted that census and consequently all their local chiefs and opinion leaders were arrested and imprisoned for a period of one year and six months in the central prison of Lubumbashi. ${ }^{34}$ Furthermore, during the democratisation process of the 1990s in Zaire/the DRC, the Tutsi were excluded from participating in the National

28 Francois Ngolet, Crisis in the Congo: The Rise and the Fall of Laurent Desire Kabila (Palgrave MacMillan Publishers 2011) 15.

29 Jason Stearns and others (n 21) 18.

30 Henning Tamm and Claire Lauterbach, Dynamic of Conflict and forced Migration in the Democratic Republic of Congo (Refugees Studies Center, University of Oxford, 2010) 3.

31 Mamdani (n 22) 7.

32 Henning Tamm and Claire Lauterbach (n 30).

33 FM Ndahinda, 'Bemba Banyamulenge Case Before the ICC: From Individual to Collective Criminal Responsibility' (2013) 7 The International Journal of Transitional Justice 476, 480.

34 Interview with some of the persons who were detained in Lubumbashi. 
Sovereign Conference (NSC) that took place between 1991 and 1992, again due to dubious nationality. That conference was supposed to draft a new constitution and set new foundations for multiparty democracy. ${ }^{35}$ The controversies over the Congolese citizenship of the Tutsi have greatly contributed to their discrimination in and exclusion from many aspects of life, including politics in the DRC.

Today, the issue of the citizenship of the Tutsi in the DRC seems to be legally settled because, during the Lusaka Peace Agreement which put to an end to the second war in the DRC, the parties agreed that 'all ethnic communities whose territories came to be the Congo at independence should qualify to have equal rights and protection in law as Congolese citizens. ${ }^{36}$ The same principle was also confirmed by the DRC's Constitution of 2006. ${ }^{37}$ However, although the question of the Congolese identity of the Tutsi cannot be legally questioned, in practice they are still victims of xenophobic practices and ethnic violence in the DRC. Examples are the attacks that are directed against them in the South and in the North Kivu provinces. The members of this community are also obliged to be squeezed into their provinces of origin, notably the South and North Kivu provinces, because their security cannot be fully guaranteed in other parts of the country and they are still hardly accepted by their fellow Congolese in other regions. The non-acceptance of the Tutsi as true Congolese in the DRC has also nourished the campaigns of the killings of August 1998.

\subsection{Other Major Events Marking Xenophobia Against the Tutsi in the DRC} 2.2.1 Resolution on the Expulsion of the Tutsi from the DRC of April 1995

In April 1995, the Zairian/DRC Transitional Parliament passed a Resolution to expel all the Tutsi from the DRC, starting with the Banyamulenge in South Kivu. ${ }^{38}$ Implementing this Resolution in October 1995, the administrator of the Uvira zone in South Kivu, Shweka Mutabazi, ordered the Banyamulenge to leave the high plateaus of Mulenge and go to Rwanda by qualifying them as 'an unknown ethnic group of Zaire/the DRC. ${ }^{39}$ That order was followed by many killings of Banyamulenge in the city of Uvira, Baraka, Bubembe and in the Plain of Ruzizi. Moreover, in September 1996, the former vicegovernor of the South Kivu province, Lwabanji Lwassi Ngabo, also ordered the Banyamulenge to vacate South Kivu within six days, otherwise he would order them to be burnt. ${ }^{40}$ Meanwhile, in the North Kivu province, multiple attacks against the Tutsi were being carried out by the Zairian/DRC security forces, in collaboration with Hutu militias from Rwanda recruited in the refugee camps. ${ }^{41}$ Facing discrimination and ethnic violence in their own country, the majority of youths from the Tutsi community fled to neighbouring countries in the east, notably to Rwanda and Burundi where they returned in October 1996 with the AFDL. It is this movement that overthrew the dictatorship of

\footnotetext{
35 Ndahinda (n 14) 157.

36 Inter-Congolese Political Negotiations, 'Final Act (Sun City Agreement)' (United Nations Peacemaker, $2 \quad$ April 2003) <peacemaker.un.org/sites/peacemaker.un.org/files/CD_030402_SunCityAgreement.pdf> accessed 1 December 2019, 24.

37 The Constitution of the Democratic Republic of the Congo (2005) <constitutionnet.org/sites/default/files/DRC\%20-\%20Congo\%20Constitution.pdf> accessed 1 December 2019, art 10.

38 Stearns and others (n 21) 19.

39 Manassé Ruhimbika, Les Banyamulenge (Congo-Ex Zaïre) Entre Deux Guerres (préface de B. Jewsiewicki) (L'Harmattan 2001) 299.

40 ibid.

41 Ndahinda (n 14) 159.
} 
Mobutu in May 1997 and installed the late Kabila as President of the DRC. It is incontestable that authorities in the DRC tried and failed to expel the Tutsi from the DRC several times. Following the speeches of several DRC authority figures, including Yerodia and the late President Kabila, during the outbreak of the war in August 1998, the killing of the Tutsi was a way to remove them once and for all from the DRC's territory.

\subsubsection{Influx of Hutu Refugees from Rwanda and Burundi to the DRC in 1993-1994}

The massive arrival of the Hutu refugees from Burundi and Rwanda between 1993 and 1994 also increased the xenophobia against the Tutsi in the DRC. Those who came from Burundi had fled the inter-ethnic conflict that took place between 1993 and 1994 and those who came from Rwanda crossed into Zaire/the DRC after the 1994 genocide of the Tutsi. ${ }^{42}$ During that period, relations between the Kinshasa leadership and the regimes in Kigali and Bujumbura were not good. Therefore, the late President Mobutu seized the opportunity to work closely with these refugees by providing them with military training, so that they could help him deal with any threat that might come from Eastern Zaire/the DRC. Combatants from the refugee camps also took advantage of the situation to destabilise their countries of origin. ${ }^{43}$ Among these refugees were some who had participated in ethnic violence in their home countries, including those who participated in the 1994 genocide of the Tutsi in Rwanda. Hence, they have greatly contributed to spreading hate against the Tutsi in Zaire/the DRC. Testimonies from the survivors of the massacres of August 1998 have implicated some of the Hutu refugees in these heinous crimes. Illustratively, they are alleged to have participated in the killings which took place in the two Kivu provinces as well as in Vyura, Kalemie, Kamina and Lubumbashi in the former Katanga province. ${ }^{44}$ This also explains that the international crimes in which Yerodia was involved in August 1998 in the DRC were nourished by a cross-border ideology against the Tutsi that prevailed in the countries of the Great Lakes Region.

\subsection{Immediate Causes of the 1998 War and the Massacres of the Tutsi in the DRC}

When the conflict broke out in August 1998, the DRC government quickly qualified it as a Tutsi-led rebellion supported by Rwanda and Uganda and therefore called for extermination of the Tutsi in the DRC. However, the international crimes committed during this period were at the origin of the dispute between the DRC and Belgium at the ICJ. ${ }^{45}$ The examination of the immediate triggers of these massacres is essential in order to understand the context in which the crimes in question were committed.

\subsubsection{The Struggle for Power}

Some partially concurred with the DRC authorities that the 1998 war was initiated by Uganda and Rwanda in order to protect their security and economic interests in the region. ${ }^{46}$ However, there is also disagreement. According to Francois Ngolet, shortly after

42 The United Nations Economic Commission for Africa, 'Conflict in the Democratic Republic of Congo: Causes, Impact and implications for the Great Lakes Region' (Economic Commission for Africa, 2015) 14.

43 International Crisis Group (ICG), 'The Kivus: The Forgotten Crucible of the Congo Conflict' (African Report no 56, Nairobi/Brussels, 2003) 5.

44 Testimonies from the survivors.

45 Case Concerning the Arrest Warrant of 11 April 2000 (Democratic Republic of the Congo v Belgium) (n 6).

46 Koen Vlassenroot and Timothy Raeymakers, 'New Political Order in the DR Congo? The Transformation of Regulation' (2008) 21 Afrika Focus 39, 43. 
the takeover of powers in Kinshasa, President Kabila started to rule over the DRC along with the majority of people from his own tribe, namely the Lubakat from Katanga ${ }^{47} \mathrm{He}$ began to appoint them to different key strategic positions in the government, army and police as well as in the intelligence service. ${ }^{48}$ In particular, most of the people - mainly Tutsi - who had fought alongside him against Mobutu were excluded from the circle of power.$^{49}$ For example, his former Army Chief of Staff, General Masasu Nindaga, who was half Tutsi and half Mushi, was arbitrarily accused of conniving with foreign intelligence services and was later murdered. After his killing, the report of the International Crisis Group later revealed that General Masasu Nindaga was killed because he had discovered that the secret service of the late President Kabila weas recruiting and providing arms to the Hutu refugees from Rwanda and Burundi in Eastern DRC. ${ }^{50}$

It is true that many politicians and soldiers from the Tutsi community had joined the rebellion of August 1998. However, those whom I contacted during the writing of this paper attribute this to their discrimination and marginalisation by the regime of the late President Kabila. ${ }^{51}$ Moreover, the fact that some Tutsi politicians and soldiers joined the rebellion should not have been a reason to call for the extermination of the entire Tutsi community in the DRC.

It is also important to mention that among the rebels who were fighting against the Kabila regime during that period were regrouped people from different backgrounds in the DRC: for example, the political leaders of the Congolese Rally for Democracy movement (RDC), notably Professor Arthur Zaid Ngoma (a Murega from the Maniema province), Professor Ernest Wamba dia Wamba (a Mukongo from the Bas-Congo province) and Jean Pierre Ondekane, the military commander of the movement (a Ngbaka from the Equateur province in North-East Congo).

Considering the nature of the conflict and those who were involved, it is clear that belligerents were fighting for power at a high level, which led to an armed conflict. In fact, the late President Kabila and members of his inner circle wanted to control power, while the rebels, who were mostly composed of those who fought alongside him against Mobutu, were against that style of governance. Considering their history of discrimination and marginalisation in the DRC, the Tutsi became collateral victims because some of the politicians and soldiers from their community were among those who had opposed the Kabila regime. In that context, yet again, these massacres constituted a sign that, according to the then leadership of the DRC, the Tutsi did not deserve the same right to oppose the government as other Congolese had, a fact which amounts to discrimination.

\subsubsection{Insecurity in the Two Kivu Provinces}

After the 1997 regime change in the DRC, the populations of the two Kivu provinces hoped to regain security. In particular, the Tutsi were expecting to see their rights guaranteed, like those of other Congolese in the DRC. However, after the takeover of power in Kinshasa, they realised that the regime change itself was not enough to guarantee their security and rights. This realisation was due to the fact that in the South Kivu province, the Mai Mai (local militias) started to attack the Banyamulenge and raid their

47 Ngolet (n 28) 11-16.

48 ibid.

49 ibid.

50 International Crisis Group, 'How Kabila lost his way: The Performance of Laurent Désiré Kabila's Government' (Relief Web, 21 May 1999) <reliefweb.int/report/angola/how-kabila-lost-his-wayperformance-laurent-d\%C3\%A9sir\%C3\%A9-kabilas-government> accessed 1 December 2019.

51 Interviews with two military officials from the Tutsi ethnic group who had joined the rebellion of the Rally for the Congolese Democracy (RDC) during the outbreak of the war in August 1998 in DRC. 
cattle. In the North Kivu province, these local militias were working in collaboration with the Hutu militias from Rwanda to attack the Tutsi villages and to raid their properties. ${ }^{52}$ Despite this, in February 1998, the military leadership in Kinshasa surprisingly ordered the removal of all soldiers from the Tutsi community in the two Kivu provinces. Unfortunately, that order was not implemented because the soldiers concerned mutinied and forced their leadership to revise that decision. ${ }^{53}$

During that period, it was clear that the army high command suspected the Tutsi who were in the national army of not respecting its orders, while the Tutsi soldiers suspected the soldiers from other ethnic groups of collaborating with the Mai Mai and Hutu militias from Rwanda and Burundi to attack their villages in the two Kivu provinces. In addition to the local insurrections, rebel groups from Uganda, Rwanda and Burundi were operating in the east of the country, where they were involved in many human rights abuses. That situation increased suspicions among communities in these two provinces and led to the outbreak of the war in eastern provinces in August 1998.

\subsubsection{Conspiracy Theory on the Creation of a 'Tutsi-Hamites Empire' in Central Africa}

The term 'conspiracy theory' is defined in this article as an explanatory belief regarding certain actors meeting in secret to agree and carry out a hidden agenda that is widely regarded as malicious. ${ }^{54}$

It is clear that many of the wars that occurred in the countries of the Great Lakes region of Africa (Eastern DRC, Rwanda, and Burundi) had an inter-ethnic character and, therefore, a conspiracy theory developed around the possible creation of a 'Tutsi-Hima' empire in the Central African region. The proponents of that theory argued that the various wars which occurred in this region were nourished by a hidden regional agenda of the Nilotics to establish an empire in the region, under which the Bantu populations would be dominated. ${ }^{55}$ To them, the war against Mobutu of 1996 was not a liberation war but an ideological one for the Nilotics in which the late President Kabila was used to achieve their regional agenda. ${ }^{56}$ As this conspiracy theory was already established in the DRC when Kabila came to power in 1997, his administration experienced many difficulties in dealing with the Tutsi who worked in different institutions and in the security forces. This was because some members of the population of the DRC did not consider the Tutsi as people who were serving their nation; rather, they were seen as having a hidden agenda. The Hutu extremists used the same theory in Rwanda during their sensitization campaigns to exterminate the Tutsi in 1994. The artisans of the theory considered the war that began in Rwanda in 1990 against the Habyarimana regime (that of the former Rwandan president) as a means of creating a 'Tutsi zone' comprising Uganda, Rwanda, Burundi, and the Kivu regions of Zaire/the DRC. ${ }^{57}$ In the DRC, this conspiracy theory was mostly spread by politicians from the two Kivu provinces and was later fueled by the arrival of the Hutu refugees from Rwanda and Burundi following the inter-ethnic conflicts of the 1990s in these countries.

52 International Crisis Group (n 50) 6.

53 Ngolet (n 28) 16.

54 Jan-Willem van Prooijen and Karen Douglas, 'Conspiracy Theories as Part of History: The Role of Societal Crisis Situations' (2017) 10 Memory Studies 323, 324.

55 Ndahinda (n 33) 480.

56 John Clark, The African Stakes of the Congo War (Palgrave Macmillan 2004) 147.

57 Tom Ndahiro, 'Genocide and Myth of the Hima-Tutsi-Empire in the Great Lakes Region of Africa' (2016) (Umuvugizi, 27 July 2016) <umuvugizi.wordpress.com/2016/07/27/genocide-and-myth-of-thehimatutsiempire/> accessed 1 December 2019. 
When Yerodia was asked why he called for the extermination of the Tutsi during the outbreak of the second war in the DRC, his response was that he believed that the war had the purpose of exterminating the Bantu populations in the Central African region. ${ }^{58}$ The former president of Zimbabwe, Robert Mugabe, gave almost the same answer when he was asked why he supported the Kinshasa regime during that war. He mentioned that his army went to prevent the expansion of the Tutsi-Hamites Empire in the center of Africa. ${ }^{59}$ This conspiracy theory has been used to fuel inter-ethnic violence in the countries of the Great Lakes Region and has already resulted in many Tutsi victims, including those of August 1998 in the DRC. At present, this conspiracy theory still threatens the security of the Tutsi in the DRC and thus constitutes one of the obstacles to victims of the massacres of August 1998 in accessing justice in the domestic courts of the DRC.

\section{The Yerodia Case at the ICJ: Whose Justice (Victims or Perpetrators of International Crimes)}

In its judgment of February 2002, the ICJ confirmed that the arrest warrant issued by Belgium against Yerodia violated customary international law concerning the absolute inviolability and immunity from criminal proceedings for incumbent Foreign Ministers. ${ }^{60}$ However, the international crimes of which Yerodia was accused were committed before he became Foreign Minister and the ICJ rendered its decision when he had ceased to hold such position. The thorny question remains as to whose justice this judgment serves.

\subsection{The Chronology of Events in the Yerodia Case at the ICJ}

The international crimes of which Yerodia was accused were committed in August 1998, when he was a Private Secretary and Chief of Cabinet of President Kabila. Belgium issued an arrest warrant against him on 11 April 2000, when he was Foreign Minister. ${ }^{61}$ His case was brought before the ICJ on 17 October 2000, with the DRC accusing Belgium of having violated the diplomatic immunity of its Foreign Minister in office. ${ }^{62}$ However, one month later, in November 2000, Yerodia was demoted from the position of Foreign Minister and appointed as Minister of Education, a post that he occupied until April 2001. ${ }^{63}$ On 14 February 2002, the ICJ rendered its judgment, in which it confirmed the DRC's complaint and requested Belgium to cancel the arrest warrant because it violated the diplomatic immunity of an incumbent Foreign Minister, without considering the time when the relevant crimes took place and the changes that had occurred in Yerodia's position during the proceedings.

\subsection{Immunity of Senior State Officials Under International Law}

As a general rule, immunity is a privilege that is attached to certain positions or status of particular persons, entities, or properties and which is normally used to exclude the

58 Gerard Prunier, Africa's World War: Congo, the Rwandan Genocide, and the Making of Continental Catastrophe (Oxford University Press 2010) 419.

59 Eric Kashambuzi, 'Is the Creation of Tutsi Empire Real or Imaginary?' (Kashambuzi, 14 October 2012) $<$ kashambuzi.com/is-creation-of-tutsi-empire-real-or-imaginary/> accessed 1 December 2019.

60 Malcolm Evans, International law (3rd ed, Oxford University Press 2010) 395.

61 Case Concerning the Arrest Warrant of 11 April 2000 (Democratic Republic of the Congo v Belgium) (n 6) [3].

62 Amanda Nelson, 'Democratic Republic of Congo v. Belgium: The International Court's Consideration of Immunity of Foreign Ministers from Criminal Prosecution in Foreign States' (2003) 19 New York Law School 859.

63 Case Concerning the Arrest Warrant of 11 April 2000 (Democratic Republic of the Congo v Belgium) (n 6) [9]. 
exercise of jurisdiction over them. ${ }^{64}$ Several arguments have been advanced as to the reasons for the granting of immunity, though most of them are based on legal fiction. The first is the 'extraterritoriality theory', which assumes that heads of State and diplomats, when they are abroad on missions, are still considered as being in their own countries rather than in the host State. ${ }^{65}$ The second is the personification or representative theory, which considers heads of State or diplomats as holders of the collective powers of their States within their host States when they are on missions abroad. ${ }^{66}$ The third argument is that of 'functional necessity'. Under this theory, heads of State and diplomats need special protection during the tenure of their office or whilst abroad in the performance of their duties. ${ }^{67}$ Article 29 of the Vienna Convention on Diplomatic Relations of 18 April 1961 also provides that 'the purpose of diplomatic privileges and immunities is to ensure the efficient performance of the functions of diplomatic missions as representing States. ${ }^{168}$ According to Article 21, Paragraph 2 of the New York Convention on Special Missions of December 1969:

\footnotetext{
The Heads of the Governments, the Foreign Ministers and other persons of high rank, when they take part in a special mission of the sending State, shall enjoy in the receiving State or in a third State, in addition to what is granted by the present Convention, the facilities, privileges and immunities accorded by international law. ${ }^{69}$
}

This explains that the logic behind the functional immunity is to protect the persons mentioned above against any act of a foreign authority that would prevent him or her from conducting diplomatic activities freely. In other words, functional immunity serves to protect the activities that someone is carrying out and this is precisely what the DRC complained of when it instituted proceedings against Belgium before the ICJ.

\subsection{Who Benefited from the ICJ's Judgment in the Yerodia Case?}

At the time of the ICJ's judgment, Yerodia had not occupied the post of Foreign Minister of the DRC for a year and a half. Despite this, the ICJ based its conclusions on the functional need to protect his diplomatic activities abroad. The Court emphasised that 'the functions of a Foreign Minister are such that, throughout the duration of his or her office, he or she when abroad enjoys full immunity from criminal jurisdiction and inviolability.'

On one hand, the ICJ confirmed that the purpose of such immunity is to enable foreign ministers to freely conduct international relations on behalf of their countries. On the other hand, the Court's decision created a dilemma because it was rendered after Yerodia had ceased to carry out such activities on behalf of the DRC. In fact, Yerodia had ceased to occupy any ministerial position in the DRC; at that moment he was a Senator. Clearly, the diplomatic immunity of which the ICJ ruled in favour in this case had no real meaning because there was a disconnect between the motivation behind the judgment and the facts. Consequently, the immunity in question only served to protect a perpetrator of

64 Dapo Akande and Shah Sangeeta, 'Immunities of State Officials, International Crimes, and Foreign Domestic Courts' (2011) 21 European Journal of International Law 815, 818.

65 Darryl Robinson, 'The impact of Human Rights Accountability Movement on the International Law of Immunities' (2016) 40 Canadian Yearbook of International Law 151, 157.

66 ibid.

67 Akande and Sangeeta (n 64) 18.

68 The Vienna Convention on Diplomatic Immunities and Privileges (adopted 18 April 1961, entered into force 24 April 1964) 500 UNTS 95.

69 Convention on Special Missions (adopted 8 December 1969, entered into force 21 June 1985) 1400 UNTS 231. 
international crimes from criminal responsibility, to the detriment of victims' right to access justice.

\section{The Preventive Nature of Diplomatic Immunities v the ICJ's Decision in the Yerodia Case}

In its decision, the ICJ confirmed that the arrest warrant which had been issued by Belgium against Yerodia violated the immunity that incumbent foreign ministers enjoy under international law in foreign domestic courts. This is a well-known rule in public international law. ${ }^{70}$ However, considering the changes in Yerodia's position, specifically the fact that Yerodia was no longer the Foreign Minister of the DRC at the time of the judgment, Belgium objected to that decision.

\subsection{Belgium Objects After Changes to Yerodia's Position during the Proceedings before the ICJ}

After Yerodia's removal from the position of Foreign Minister during the proceedings, Belgium objected to the jurisdiction of the ICJ in his case. Belgium argued that, from the moment Yerodia had ceased to occupy the post of Foreign Minister, the dispute between it and the DRC before the ICJ had ceased to exist. Belgium also reminded the ICJ that if the Court wished to proceed with the case until the final decision, its nature had changed and it had become a diplomatic protection case in which Yerodia had not exhausted domestic remedies. ${ }^{71}$

However, all objections put forward by Belgium were rejected and the ICJ ruled that its jurisdiction would be determined at the time a case is filed with it. Moreover, the ICJ ruled that the changes which had occurred in relation to Yerodia's position during the proceedings did not put an end to the dispute between the parties and had no effect on its object. $^{72}$ Therefore, the ICJ concluded that the question of the lawfulness of the arrest warrant issued against Yerodia remained a pending issue as far as the case had not changed into one of diplomatic protection. ${ }^{73}$ Considering these changes, the decision of the ICJ in this case was not pragmatic, but rather a mechanical application of immunity.

\subsection{The Non-Pragmatic Character of the ICJ's Decision in the Yerodia Case}

It is a mammoth task to challenge the judgment of an international court such as the ICJ, but the reason it made progress in the Yerodia case which obstructed its continuation in Belgium was not pragmatic. Some scholars even criticised it as contradicting the current trend and willingness of the international community to prosecute international crimes. ${ }^{74}$ Others argued that it lacked the balance between the interests and values underlying this dispute, which were on one hand the fight against the most heinous crimes and on the other hand the maintenance of smooth collaboration between States. ${ }^{75}$ In reality, the

70 Neil Boister, 'The ICJ in the Arrest Warrant Case: Arresting the Development of International Criminal Law' (2002) 7 Journal of Conflict \& Security Law 293.

71 Golden Gate University School of Law, 'Arrest Warrant of 11 April 2000 (Democratic Republic of the Congo v. Belgium) International Court of Justice 14 February 2002' (2002) 8 Annual Survey of International \& Comparative Law 151.

72 ibid.

73 ibid.

74 Andrew Coleman, 'The International Court of Justice and Highly Political Matters' (2003) 4 Melbourne Journal of International Law 29, 32.

75 Chrisoph Schreuer and Stephan Wittich, 'Immunity v. Accountability: The ICJ's Judgment in the Yerodia Case' (2004) 4 International Law Forum Du Droit International 117, 120. 
decision completely disregarded the preventive nature of the DRC's application before the ICJ.

From the outset, the DRC persistently complained about violation of the immunity belonging to its acting Foreign Minister, as the arrest warrant would prevent him from conducting diplomatic relations freely abroad. The ICJ's decision in this case was also based on the functional immunity of an incumbent Foreign Minister, a position which requires substantial foreign travel, which would be deterred by the existence of an international arrest warrant.

In fact, when the ICJ rendered its judgment in this decision, Yerodia was not vested with the power to conduct such activities. Further, the ICJ did not provide any objective explanation in its judgment as to why its jurisdiction must be determined at the time a case is filed rather than when its decision is rendered or when the alleged violations (in the present case international crimes) took place. Hence, the objections that were advanced by Belgium to contest the jurisdiction of the ICJ after the change in the position of Yerodia were pragmatic, as during that period he was a former foreign minister who had no responsibility to conduct international relations on behalf of the DRC. In other words, in that decision, there is a contradiction between the ICJ's argumentation and the status of Yerodia at the time of the judgment.

In short, the arguments of the ICJ to reject Belgium's objections were not grounded in international law. The Court's decision makes it clear that, instead of adjudicating a practical case that was presented before it for ruling, the judges merely developed theories around the immunity of incumbent foreign ministers in general.

\subsection{Mechanical Application of Immunity by the ICJ in the Yerodia Case}

The ICJ is an interstate court created under the United Nations Charter of 1945, with a mandate to adjudicate interstate disputes submitted to it. ${ }^{76}$ This Court can also receive disputes between States on behalf of their nationals who have suffered harm at the hands of another State and such a dispute remains between the States. ${ }^{77}$ However, despite the fact that the Yerodia case was instituted by the DRC against Belgium, the judgment in this case only contributed to shielding Yerodia from criminal responsibility rather than preserving the smooth operation of the DRC's diplomatic activities abroad. In other words, the application of immunity in this case by the ICJ was purely mechanical. As a result, this decision was used to serve an interest that it was not intended to protect. Furthermore, it is unfortunate that from February 2002, when the ICJ rendered its decision in the Yerodia case, no case in relation to the international crimes in which he was involved has been initiated elsewhere. This proves that the judgment contributed to closing the doors to victims in their endeavor to access justice, either in the DRC or in other foreign forums. Hence, the beneficiary of this situation is the suspect of international crimes, to the detriment of victims' right to access justice.

\section{Access to Justice for Victims of Yerodia's International Crimes}

In order to access justice, victims must first find a judicial body that is willing to hear their case. Domestic jurisdictions always have the competence to address international crimes and under specific conditions, foreign jurisdictions also have this competence. When government authorities are alleged to be involved in the perpetration of such crimes,

76 Statute of the International Court of Justice (adopted 26 June 1945, entered into force 24 October 1945) 33 UNTS 993 art 34(1).

77 ibid arts $36-38$. 
victims often face many difficulties in accessing justice in domestic courts and therefore lose confidence in their national justice system. It is precisely in this context that victims of Yerodia's international crimes brought their case in Belgium. Unfortunately, through the ICJ's judgment, the DRC's government obstructed the continuation of the case in Belgium. The remaining question is the impact of the decision on the victims of Yerodia's international crimes, regarding their access to justice in domestic and foreign courts.

\subsection{The Impact of the ICJ's Decision on Access to Justice for Victims of Yerodia's Intentional Crimes in the DRC}

Until the Second World War, international law considered the treatment of citizens by their States as an internal issue. However, after the horrific crimes which occurred during that War, States began to be aware of the limits of their sovereignty over the human rights of the persons under their control. ${ }^{78}$ Consequently, many human rights instruments currently recognise the principle of aut dedere aut judicare: extradite or prosecute. ${ }^{79}$ This principle obliges States either to prosecute suspects of international crimes or to extradite them to where they can be properly prosecuted. The idea behind this principle is to ensure that no suspect of international crimes can go unpunished.

The DRC is a State party to many international human rights instruments guaranteeing the respect for human rights and which contain the principle of aut dedere aut judicare, such as the International Covenant on Civil and Political Rights, the International Convention on the Elimination of All Forms of Racial Discrimination, the Convention on the Prevention and Punishment of the crime of Genocide as well as the Convention against Torture and other Cruel Inhuman and Degrading Treatment and Punishment. ${ }^{80}$ At the regional level, the DRC is also a State party to the African Charter on Human and Peoples' Rights as well as its Protocol on the Establishment of the African Court of Justice and Human Rights. ${ }^{81}$ Moreover, the DRC's Constitution provides many rights, including the right to life and physical integrity, the right to non-discrimination, the right not to be subjected to cruel, inhuman, and degrading treatment and the right to access justice. ${ }^{82}$

Shortly after Yerodia's accusation in Belgium, he was appointed Minister of Education and later became a Senator, a position that had provided him with immunity from criminal prosecution before national courts. Therefore, the ICJ's decision in the Yerodia case has somehow confirmed the sovereignty of the DRC in dealing with his international crimes, thus leaving victims without any further recourse to national courts.

However, the non-prosecution of suspects of international crimes in the DRC, such as Yerodia, is a failure of the DRC's government to fulfill its international obligations and its own Constitution. This situation reinforces the reign of impunity in that country and encourages the reoccurrence of the same crimes. In addition, the efforts deployed by the DRC's government in the Yerodia case at the ICJ have also revealed to victims and their supporters its determination to prevent any trial regarding the international crimes of

78 Naomi Roht-Arriaza, 'State Responsibility to Investigate and Prosecute Grave Human Rights Violations in International Law' (1990) 78 California Law Review 451, 462.

79 ibid 463.

80 International Bar Association and Legal Assistance Consortium, 'Rebuilding Courts and Trust: An Assessment of the Needs of the Justice System in the Democratic Republic of Congo' (International Security Sector Advisory Team, August 2009) <issat.dcaf.ch/Learn/Resource-Library/Policy-andResearch-Papers/Rebuilding-Courts-and-Trust-An-Assessment-of-the-Needs-of-the-Justice-System-in-

81 the-Democratic-Republic-of-Congo> accessed 1 December 2019, 15.

ibid.

82 The Constitution of the Democratic Republic of the Congo (n 37) arts 13-14, 16, 19. 
which Yerodia was accused. In other words, the ICJ's decision in this case has silenced victims in their quest for remedies in national jurisdictions.

\subsection{The Impact of the ICJ's Decision on Access to Justice for Victims of Yerodia's Intentional Crimes in Foreign Domestic Courts}

Although the ICJ's decision in the Yerodia case was in support of his immunity, at the same time it emphasised that this immunity is not synonymous with impunity. The ICJ identified four situations in which a Foreign Minister can generally be prosecuted by foreign jurisdictions. The first situation is where international law does not provide immunity for Foreign Ministers before national jurisdictions. The second situation is when such immunity has been revoked by one's own country. The third is when a Foreign Minister ceases to hold such a position. The fourth is that, before certain international criminal courts such as the ICC, when they have jurisdiction, a Foreign Minister cannot invoke his/her immunity. ${ }^{83}$

It is unfortunate that, at the time of the ICJ's judgment, it was already clear that Yerodia would not be affected by any of these situations. This is because, in the first and the second situations, the State concerned must be willing to prosecute or to revoke the immunity of its Foreign Minister. ${ }^{84}$ In Yerodia's case, although he was not covered by immunity under international law in domestic courts, the ICJ's judgment was handed down when he was covered by another immunity provided for under national law. At that particular moment he was a member of the Senate in the DRC and, as senators enjoy immunity in domestic courts, the possibility of prosecuting him in national courts or the willingness to revoke his immunity was already non-existent. Concerning the third situation, the ICJ was incorrect to rule in favour of Yerodia's immunity because, in fact, this immunity became inoperative when he was removed from his position as Foreign Minister. As is usual, after his removal from that position, the DRC appointed another Foreign Minister who oversaw its international relations and who enjoyed the same immunity that Yerodia enjoyed after the ICJ's decision in his case. In other words, by ordering Belgium to cancel the arrest warrant and claiming that Yerodia was still covered by immunity under international law while he was no longer Foreign Minister, the ICJ simply claimed the opposite regarding the third situation. Concerning the fourth situation, at the time of the ICJ's judgment there was not a special international tribunal for the DRC. The DRC ratified the Statute of the International Criminal Court in April $2002,{ }^{85}$ two months after the ICJ's decision in the Yerodia case. This Statute entered into force for the DRC on 1 July 2002 which means that it had no jurisdiction over the crimes of which Yerodia was accused, under the principle of non-retroactivity of its jurisdiction. ${ }^{86}$

As argued by Darryl Robinson, immunity is an exception to the general rule that gives States jurisdiction over all persons under their control. Any confirmation of such immunity must be dictated by an interest to serve important societal and international interests. ${ }^{87}$ However, this was not the scenario in the Yerodia case at the ICJ, as its ruling

83 Case Concerning the Arrest Warrant of 11 April 2000 (Democratic Republic of the Congo v Belgium) (n 6) [22].

84 Alain Winants, 'The Yerodia Ruling of the International Court of Justice and the 1993/1999 Belgian Law on Universal Jurisdiction' (2003) 16 Leiden Journal of International Law 491, 498.

85 The International Criminal Court (ICC), 'The Democratic Republic of Congo: Situation in the Democratic Republic of Congo' (International Criminal Court) <icc-cpi.int/drc> accessed 1 December 2019.

86 Rome Statute of the International Criminal Court (adopted 17 July 1998, entered into force 1 July2002) 2187 UNTS 90 (Rome Statute) art 11(1).

87 Darryl Robinson, 'The Impact of the Human Rights Accountability Movement on the International Law of Immunities' (2002) 40 Canadian Yearbook of International Law 151, 155. 
in favour of Yerodia's immunity only shielded him from prosecution by foreign courts and has jeopardised the victims' right to access to justice in foreign courts. Although the change in Yerodia's position of November 2000 was already a strategy by the DRC to protect him from being prosecuted abroad, the ICJ's decision reinforced that measure as it expressly ruled in favour of his immunity. It is also evident that after a decision by an institution like the ICJ, other countries will be reluctant to accept complaints from victims against Yerodia and other suspects in relation to similar international crimes.

\section{Conclusion}

Since its independence in 1960, the DRC has experienced several epochs of conflict in which thousands of people have lost their lives through inter-ethnic violence. Some were caused by members of different communities fighting amongst themselves and many others were the result of political manipulations orchestrated by certain politicians in order to achieve their political ambitions. Moreover, most of the crimes committed as a result of this violence remain unpunished, a situation which has, many times, led to their reoccurrence. The massacre of the Tutsi of August 1998 is one of these tragic events which was orchestrated by politicians, and in which victims were targeted because of their ethnicity, and its perpetrators remain unpunished. These massacres were triggered by Yerodia's and the late President Kabila's speeches advocating racial hatred during the outbreak of the war in August 1998 in the DRC. These high-ranking officials accused the Tutsi, as a community, of conniving with foreign countries, notably Uganda, Rwanda, and Burundi, to destabilise the DRC, and called members of other Congolese communities to exterminate them. In their messages, broadcast in international media, they described the Tutsi as 'Scum and vermin that must be methodically eliminated and with determination.' These speeches were followed by concrete acts in which thousands of Tutsis lost their lives.

However, although DRC officials used the outbreak of the war in August 1998 to justify these horrific crimes, it is evident that, for many years, the Tutsi have been victims of discrimination and other forms of injustices in the DRC because of their ethnicity. Since the colonial era, Tutsi in the DRC were denied the right to customary power and therefore excluded from governance. From the post-independence conflict until today, Tutsi in the DRC have also been frequently targeted because of their origin during the successive wars that occurred in the DRC. Moreover, their Congolese identity was repeatedly manipulated by different politicians for their political purposes. These facts and others were among the direct precursors to their massacres of August 1998.

As to the security context that prevailed in the DRC during that period, there were already three intertwined wars going on. First, there was a local conflict which resulted from intercommunity resentments inherited from the colonial period in the two Kivu provinces. The second was a national conflict resulting from general governance issues in the DRC. The third was a regional conflict resulting from the insecurity that was prevailing in all the countries of the Great Lakes region, due to the presence of a high number of refugees and uncontrolled combatants across the region. In particular, the conspiracy theory around the possible creation of the 'Tutsi-Hamites' empire in the Central African countries, which was propagated in the countries of that region, constituted an additional threat to the security of Tutsi in the DRC during this period.

The international crimes committed in August 1998 during the massacres of the Tutsi were at the origin of a dispute between the DRC and Belgium at the ICJ. The dispute arose from an international arrest warrant that an investigating judge of a First Instance Tribunal of Brussels had issued against Yerodia, who at the time of the issuance of this arrest warrant was Foreign Minister, for crimes against humanity and war crimes. However, the crimes in question were committed before Yerodia had become Foreign 
Minister and the ICJ rendered its decision a year and a half after he left office. Despite this, the ICJ ruled in favour of his immunity from prosecution in foreign courts. As the reason for granting such immunity is to avoid any act of foreign authority that could hinder diplomats in the performance their duties abroad, the ICJ's decision in the Yerodia case completely disregarded the preventive nature of such immunity. Since it was issued when Yerodia was no longer a Foreign Minister, it contradicted the rationale behind such immunity under international law. In the same decision, the ICJ provided no objective justification under international law as to why its jurisdiction must be determined at the moment when a case is filed before it rather than at the moment it renders its decision.

Although the ICJ's judgment in this case did not directly address the issue of the international crimes of which Yerodia was accused, it contributed to shielding the suspect from being brought to justice, both in domestic and foreign courts. Moreover, the efforts deployed by the DRC to obstruct the continuation of this case in Belgium have also revealed to victims and their supporters its determination to prevent the commencement of any proceedings against the perpetrators of the above-mentioned crimes anywhere. Further, after the ICJ's decision in this case, no other case was brought elsewhere regarding Yerodia's international crimes. After a decision of such a highly regarded international institution, it is clear that countries will be reluctant to receive complaints from victims in relation to the same case.

Finally, the ICJ's decision in the Yerodia case has also left victims in the hands of those who have deployed enormous efforts to shield the perpetrators of their crimes from justice, a fact that has reduced them to silence in their quest for justice. 